\title{
Innovation Management Practices, Strategic Adaptation, and Business Results: Evidence from the Electronics Industry
}

\author{
Alba Sánchez', Alejandro Lago², Xavier Ferràs ${ }^{3}$, Jaume Ribera $^{4}$
}

\begin{abstract}
This research contributes to the understanding of how different practices of innovation management are related to mid- and long-term growth and profitability. Governments and regional development agencies invest relevant budgets to foster innovation in small and medium enterprises (SMEs) and improve their innovation management practices to make them more competitive. Nevertheless, it is not clear what impact these practices have on a company's performance over a long period of time. We propose a model to audit and classify innovation practices and empirically test the impact of innovation practices on the firms' long-term financial performance, using a broad sample of companies in the electronics sector. Our empirical results show that, within a regional context, companies that are similar in terms of size, position in the value chain, and ownership structure follow similar innovative practices. Furthermore, the use of a systematic approach for innovation leads to revenue growth but does not necessarily increase profit or productivity.
\end{abstract}

Keywords: Innovation management; strategic adaptation; business results; technology management; product management.

\footnotetext{
'Business Innovation Centre, ACCIÓ - Government of Catalonia, Passeig de Gràcia 129, 08008, Barcelona, Spain. Phone: +34.93.567.68.70; Email: asanchezna@acc10.cat Corresponding author ${ }^{2}$ Operations Management department, IESE Business School, Universidad de Navarra, Av. Pearson, 2I, Barcelona 08034, Spain. Phone: +34.93.253.42.00; Email: alago@iese.edu

${ }^{3}$ Business Innovation Centre, ACCIÓ - Government of Catalonia. Passeig de Gràcia 129, 08008, Barcelona, Spain. Phone: +34.93.476.73.10; Email:xferras@acc10.cat ${ }^{4}$ Operations Management department, IESE Business School, Universidad de Navarra, Av. Pearson, 2I, Barcelona 08034, Spain. Phone: +34.93.253.42.00; Email: jribera@iese.edu
} 


\section{Introduction}

Since the beginning of the 2 lst century innovation has been one of the fundamental aspects of industrial and economic development policies in Western countries. The political agenda in most advanced economies always includes programs aimed to improve innovation capabilities of companies in order to create different products and services. In part, this institutional trend has been spurred by the traditional academic support of innovation as a key capability for the long-term sustainability of companies. Schumpeter (1934) pointed early in the 20th century at the importance of innovation as a driver for economic growth. Later, Porter (1980) proposed that the competitiveness of nations depended on the ability of an industry to innovate and improve, and that companies achieve competitive advantage through innovation. Thus innovation has proved to be important at the company level as well as on a national level. The theoretical and empirical analysis accumulated over the last few decades about the impact of innovation management on performance, however, have brought only a few conclusive results, especially at the single-company level (Tidd, 2006).

The theoretical link between innovation and company competitiveness from a long-term perspective can be traced back to the early definition of strategic adaptation. According to this stream of research, the process of strategy is considered a dynamic process, with adaptation being the key aspect needed to achieve competitive advantage in a long-term perspective (Miles \& Snow, 1978; Floyd \& Lane, 2000; Child, 1997). The process of adaptation is not seen as an uncontrolled phenomenon, but rather as the result of complex interactions that consider the changes in the external environment on one side, and, on the other side, the internal environment (existing resources, organizational structure and managers' profiles of the company, company characteristics, size, patrimonial structure, etc). Finally, the process of adaptation is affected by previous decisions on strategic positioning. This "systemic" approach tries to reconcile contingency theory and strategic positioning thinking, and distinguishes between two intertwined dynamics: an internal structuring (internal actions addressed to adapt organizational agents to new environmental conditions) and an external structuring (actions that modify the firm's relationship with its environment, such as launching new products or changing suppliers); see Child, 1997.
In the field of Innovation Management, the same concepts havebeenapproachedfromasomewhatrelated perspective. Hult et al. (2004), for instance, defines innovation as "The way to change the organization, as a response to external or internal changes or as a proactive attempt to change this environment." Hult further states that, "As the environment is changing, firms must adopt innovations along the time, and, what is more important, innovations are those activities that let the company gain competitive advantages, contributing thus to its effectiveness and business success." Hence, innovation is considered one of the key strategic "processes" that may help companies adapt both internally and externally. Damanpour (1991), Henard \& Szymaski (200I), and Grant (2005) arrive at similar conclusions. Nevertheless, the conceptual link between innovation practices and strategic alignment is not yet well understood, as the different terminologies and models make it difficult to establish the relationship between different concepts (Adams et al, 2006).

Moreover, the ability to innovate has been widely considered one key success factor of business survival and performance (Schumpeter, 1934; Burns \& Stalker, 1961; Porter, 1990). As such, different measures have been proposed and tested empirically to assess the degree of a company's innovative ability (Barclay, 1992; Kim and Oh, 2002), and the relationship between innovative ability and business performance has been widely analyzed at the industry level (Huff, 1990; Cooper and Kleinschmidt, 1991; Sorescu, Chandy, and Prabhu, 2003; Guan et al., 2009). This stream of research, however, has mainly focused on measuring innovative ability as the monetary input to a process (e.g., R\&D spending) or as the immediate output or results (e.g., number of new products, new products' percentage of sales, number of patents approved). This approach focuses only on technological aspects, however, and neglects the actual processes that turn spending into results. Hence, it does not explicitly consider the medium- and long-term effects of innovation. In particular, it neglects the processes that are derived from internal capabilities and good innovation management practices (e.g. project management practices). These innovation processes are, needless to say, multidimensional and complex and, as such, there are several ways to measure the innovation capacities of a company, but to our knowledge no comprehensive approach has been proposed to define adequate measures that capture how 
companies adopt adequate and systematic innovation practices at the company level (Adams et al., 2006), nor is there conclusive knowledge about the relationship between innovation practices and company success in the mid- and long-term (Hult, 2004).

This paper tries to close these gaps in two ways. First, we establish a conceptual model to identify different innovation practices and how they link with the external and internal dimensions of strategic alignment. Second, we try to empirically test which innovation practices influence business results in the companies.

\section{Literature Review}

In this paper, we shall build on both the literature about strategic adaptation and the literature about innovation management practices to understand how companies structure their innovation processes. We consider that strategic alignment and innovation define a single company-wide process of change, which seeks to adapt the company to a change in the environment.

\section{I. The process of strategic adaptation}

Miles \& Snow (1978) define organizational adaptation as a "dynamic process of adjustment to the change and environmental uncertainty, of maintaining an effective alignment with the environment while internal interdependencies are efficiently managed." Child (1997), as cited above, models the strategic adaptation process as the sum of two dynamics: internal structuring (internal actions addressed to adapt organizational agents to new environment conditions) and external structuring (actions that modify the company's relationship with its environment, such as launching new products or changing suppliers). As a consequen$\mathrm{ce}$, the strategic adaptation process is performed through a set of activities including process development, product development, research, or new organization deployment.

Floyd \& Lane (2000) build on these same ideas to create a new definition of strategic adaptation that they call strategic renewal. Their definition of strategic renewal expands the concept of adaptation to changes in core competences and/or the strategic positioning of the company. Key competences are socially complex combinations of assets, knowledge, and skills on which the company's ability to create differentiated products and services are based, and distinguish it from competitors (Barney, 1991, Leonard-
Barton, 1992; Prahalad and Hamel, 1990). The strategic positioning, however, refers to the place in the market occupied by a company determined by the scope of its products relative to those of its competitors (Porter, 1980).

Later, Eunni et al. (2003) conceptualized adaptation strategy as a company's ability on one hand to obtain the correct alignment of strategy, structure, and culture (internal alignment) in order to position it competitively in the market, and on the other hand, alignment with its environment in order to successfully face changes in its environment (external alignment). In order to measure the strategic adaptability of a company, Eunni et al. (2003) group some internal alignment measures: corporate leadership (see also Collins and Porras, 1994 and Donaldson and Lorsch, 1983), strategic planning, and approach to workers (see also Delery and Doty, 1996; Youndt et al., 1996, Becker and Gerhart, 1996). He also has groups for measuring external alignment: market and customer focus, technological and innovation capacity, strategic partnerships, and corporate social responsibility (previously proposed by D'Aveni, 1994, Hamel and Prahalad, 1994; Huergo, 2006; Schmiedeberg, 2009; Lee at al., 2010).

In summary, strategic adaptation can be viewed as a process composed by a set of external responses (new products, new ways of relationships with suppliers and customers, vertical integration or disintegration, expansion or contraction of domestic markets, etc) and internal responses (redefining the company's architecture, organizational chart, incorporating new knowledge, process reengineering, new incentive systems, change in an organization's culture, etc).

\subsection{Linking strategic adaptation to innovation management practices}

Innovation is often referred as the specific set of activities that offer competitive advantages to a company. As such, an increased interested has been placed on understanding which practices affect more substantially the innovation capability of the company (Adler et alt, 1992; Verhaeghe and Kfir, 2002). Innovation can be identified directly with the concept of strategic adaptation (Eunni et al, 2005). Hence, the same literature about innovation practices gives detail about how one can fit specific innovation practices or capabilities into each dimension of strategic adaptation. 
The importance of having mechanisms for systematic management of innovation has been widely recognized and investigated (Burns and Stalker, 1961; Parker, 1982; Kanter, 1983; Leonard-Barton, 1992; Christensen, 1997). Adler et al. (1990) anticipate the need for four kinds of capabilities to sustain technological innovation at the company level (product development, advanced manufacturing capability, process innovation, and organizational flexibility). Christensen (1995) classifies technological innovation capabilities into scientific research assets, process innovation assets, product innovation assets, or design assets. Burgelman et al. (2004) explores in depth the technological innovation capabilities, or TICs (the set of organizational features and practices that support the company's technological innovation strategy). For Yam et al. (2004), "The technological innovation success depends not only on the technological capabilities of the firm, but also on other critical capabilities in marketing, organization, manufacturing, strategic planning and resource allocation."

Chiesa et al. (1996) develop an innovation audit model. This model tests a set of organizational innovation management good practices, in order to determine the firm's innovation capabilities. This model is based in the exploration of "key" innovation processes (new concept generation, new product development, process redefinition, technology acquisition), plus other "support" activities (market focus, leadership and culture, resource allocation, organizational systems). This and similar models were extensively used to foster SME innovation in countries like the United Kingdom (by DTI, the Department of Trade and Industry) and Catalonia (by CIDEM, the Center for Innovation and Business Development) from 1998 to 2002.

More recently, Yam et al. (2004) use an audit model of functional analysis, grouping the different dimensions of innovation capabilities into seven functional groups (corresponding departments) and a further dimension of learning, while Adams et al. (2006) perform an exhaustive analysis of previous innovation management models and establish common denominators based on constructs present in most models: input, knowledge management, strategy, organization and culture, portfolios, and project management and marketing.

Finally, and in order to accomplish the Lisbon EU summit proposal of "converting the EU into the most competitive, knowledge-based, economy in the world by 2010 ," the
European Commission launched an extensive program to improve SME innovation capabilities based on the AT Kearney "Innovation House" model (AT Kearney, 2006), which can be traced back to the Chiesa et al. model (1996). This model, which is one of the latest contributions about innovation management, and the start point of our research, tests innovation practices according to four main foci: innovation strategy, innovation organization and culture, innovation life cycle management, and enabling factors (Figure I):

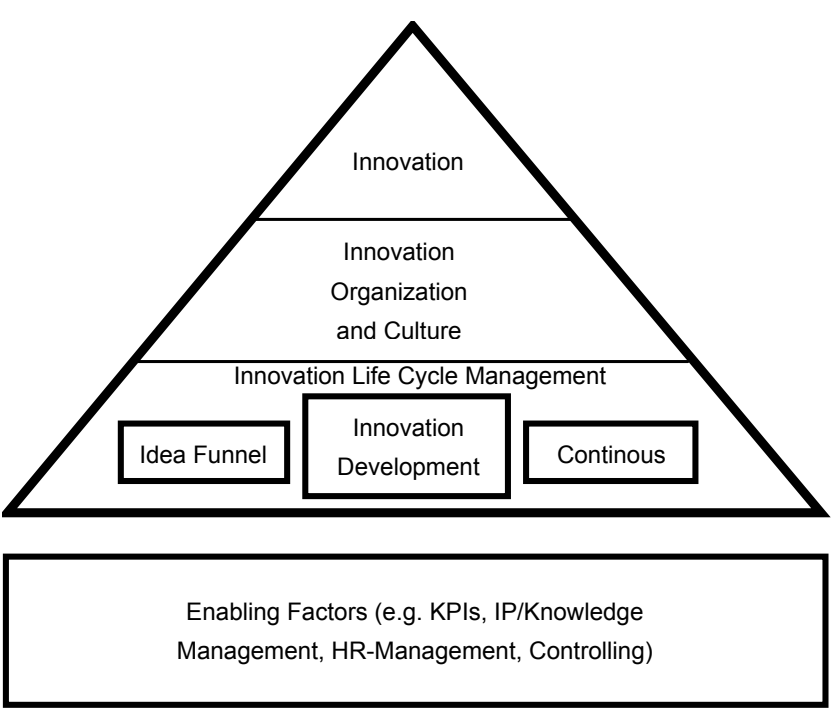

Figure I: The AT Kearney House of Innovation structures Innovation Management into four dimensions enabling success.

-Innovation strategy. Also present in models built by Terre(1999), CooperandKleinschmidt(1995), Cormicanand O'Sullivan (2004), Goffin and Pfeiffer (1999), and Burgelman et al. (2004). Chiesa (1996) identifies it partially under the heading of "leadership." This dimension means the highest level of innovative practices, and includes the creation of an innovative vision, the alignment of same with business strategy, communication and dissemination of the strategy at all organizational levels, the existence of mechanisms for competitive analysis (market trends, technologies, and competitors' moves), and objectives' measurement.

-Innovation organization and culture. A level of organization and culture, also present in models created by Cooper and Kleinschmidt (1995), Chiesa et al. (1996), Cormican and O'Sullivan (2004), and Burgelman et al. (2004). This area includes all those practices related to the systematization and evaluation of innovation, as well as tolerance to failure and risk propensity. 
-A field of "Innovation life cycle management," explicitly or implicitly present in other models. This area includes creativity processes, product lifecycle and process planning (Miltenburg, 1995), product and process innovation (Blindenbach-Driessen and Ende, 2006), and continuous improvement.

-Finally, a focus of "enabling factors" that includes activities related to technological innovation, support for the product or process innovation, knowledge management
(Coombs and Hull, 1998), information and communication technology tools, and human resources management.

\section{A Model to Link Innovation to Strategic Alignment}

Building on the literature above, we develop a conceptual framework to describe the link between business results to different innovation management practices and strategic adaptation (Figure 2).

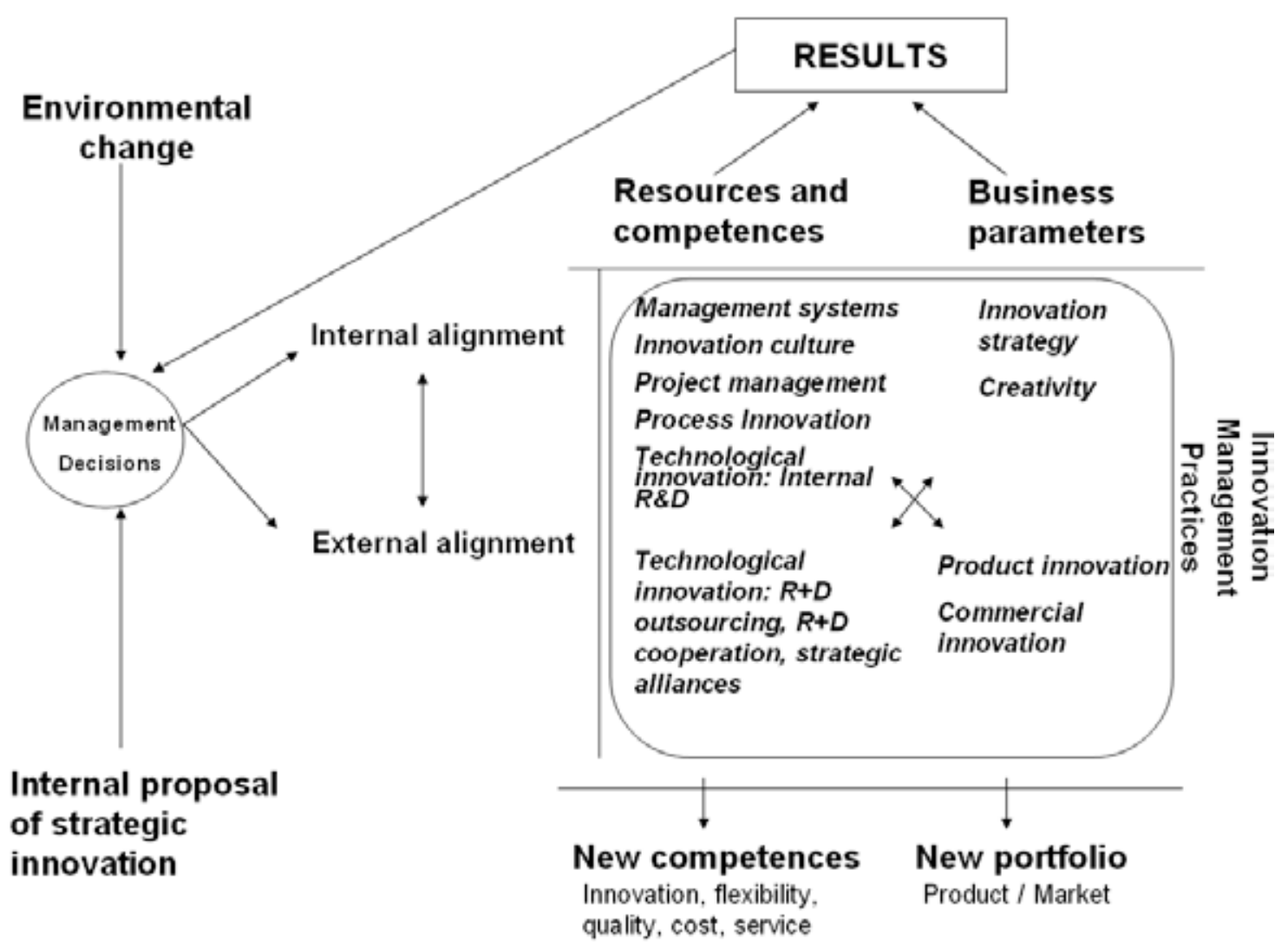

Figure 2: Proposed model to link innovation management practices, strategic alignment adaptation, and business results 
We postulate that the company adopts a series of innovation practices as a result of a strategic adaptation process. The strategic adjustment process can be triggered by any change in the environment or by an internal proposal of strategic innovation. In our analysis we shall consider these triggers as exogenous, and they will not be explicitly modeled.

We are first interested in modeling the strategic adjustment process according to two main dimensions: the response derived from adjustments, and the nature of the changes required. Regarding types of responses, we thus assume that the final goal of the strategic adaptation process is to develop new and more efficient sources of competitive advantage. To achieve this, companies can focus on two different types of dynamic responses in the fundamental way they compete, either (I) through the reordering of its resources and capacities to create new competences such as innovation, flexibility, quality, cost, and service; or (2) through the reordering of its business parameters, in terms of having a new portfolio, market, product and/or service. We believe that a combination of the two is also possible.

Regarding the nature of the process, the adjustment process may be composed of actions configured around two types of changes: an internal and external alignment. The internal alignment includes all decisions and actions made within the company's boundaries. These include actions that affect strategic formulation, organizational and architecture development, the generation of new knowledge, systems and process changes, corporate culture changes (values and behaviors), and communication of the change process. The external alignment or response includes all decisions and actions beyond the company's boundaries (actions of interoperation and exchange of information with customers, suppliers, competitors and/or the social environment). This view is consistent with previous strategic management literature affirming that, at company level, there is a set of capabilities that enables the company to survive by structuring internally and externally, and to have success in the medium- and long-term, thriving in a turbulent, dynamic environment (Child, 2007).

To link strategic adaptation to innovation management practices, our model maps the possible set of innovation business practices to the response-process matrix. Following the several models of innovation audit proposed (Chiesa et alt, 1996; Yam et al., 2004; AT Kearney, 2006), innovative management practices can be grouped around the following dimensions to describe the company's practices: innovation strategy (Cooper and Kleinschmidt, 1995; Goffin and Pfeiffer, 2004), management systems (Burns \& Stalker, 1961; Parker, 1982; Kanter, 1983; Leonard-Barton, 1992; Christensen, 1997), innovation culture (Cooper and Kleinschmidt, 1995; Chiesa et al., 1996; Burgelman et al., 2004), creativity (Miltenburg, 1995), project management (Coombs and Hull, 1998), product innovation (Miltenburg, 1995; Blindenbach-Driessen and Ende, 2006), process innovation (Blindenbach-Driessen and Ende, 2006), commercial innovation (Yam et al., 2004), and technological innovation, both internally and externally (Christensen, 1995; Hamel and Prahalad, 1994).

Note that in our model all combinations of response-process adaptation are possible. For example, strategic adaptation can be articulated as an internal response without an apparent associated external response. In this case, the area's product/market would remain the same, but some competitive capacities in the existing traditional products would increase: flexibility (adaptation to customer demands), quality, service (delivery time), cost, etc. Moreover, an external response could be articulated (with a wider range of products and services, geographic expansion, entry into a new market segment), without modifying the structure or organizational culture. The most likely adaptation, however, is formed by a set of interrelated actions and decisions, including internal and external alignment.

Finally, our model postulates that the company's innovative behavior (measured in terms of innovation management practices and their relationship to the response-process matrix) will be related to business results (Avlonitis et al., 200I; Bayus et al., 2003; Pauwels et al., 2004). A standard to define business performance is never accepted in the literature (Eunni et. al. 2005). In fact, the measurement of business success has been in the center of management research since the publication of The Principles of Scientific Management (Taylor, 1911). During the last few decades, researchers have progressively considered business performance as a complex and multi-dimensional aspect of the concept of business performance; different measures of performance, including share value, productivity, turnover, and market share growths, have been considered (Thomson, 1967; Andrews, 197I). Many times what matters is not the absolute value of the figures, but their value in comparison with the average of the industry (Porter, 1985). 
J. Technol. Manag Innov. 20II,Volume 6, Issue 2

As such, in our model business results are considered to be a multidimensional concept that may consider different measures of performance including sales growth, profitability, and returns on assets. The rationale of the selection was that sales growth explains the adaptation capability of the company, taking into account that lessadaptive companies will show turnover reduction, and vice-versa (Eunni et. al. 2005); that profit per employee explains the ratio of product renovation (i.e., the maturity of products will shift competition to cost cutting, and reduce profits, Tidd, 200I); and that return on assets is a measure of how managers allocate resources in their decision-making process. All these figures belong to the classical parameters found in the literature as measures of business performance (Tidd, 200I).

\section{Research Questions}

We have established a theoretical link between strategic adaptation, innovation management practices, and business results, and built a model to identify different innovation practices and how they link with external and internal dimensions of strategic alignment. What we want to explore, though, is if there are different typologies of companies according to innovation practices, specifically in a turbulent sector like the electronics industry (Helfat and Peteraf, 2003; Talke, 2007). Therefore, we want to empirically test which innovation practices influence business results in these companies. Our research questions, then, are thus:

RQI: Are there innovation management practices that correspond to different industrial environments?

RQ2: If so, what relationship exists between these innovation practices and business performance?

RQ3: Which innovation practices are related to business performance?

H3a: Innovation practices from internal alignment are positively related to business performance.

H3b: Innovation practices from external alignment are positively related to business performance.

\section{Methodology}

\section{I. Sample and survey instruments}

We chose the high-technology electronics industry to empirically test our model. We chose this industry because it is generally considered a "high-velocity environment, where demand, competition and technology are in constant and accelerated change" (Wirtz et al,, 2007). Therefore, the process of adaptation could be observed and results tested over a reasonable time span where performance data are available (i.e., seven to ten years). Using the "Sistema de Análisis de Balances Ibéricos" database (SABI) - the most complete database, which collects financial statement and profit and loss accounts of all the Spanish and Portuguese firms registered in the Mercantile Register - we selected a sample of 22I companies in the electronics, communications, and precision equipment groups (corresponding to groups 32 and 33 of the National Classification of Economic Activities). To be chosen for this sample group, companies had to be active before December 1999 and have from 10 to 200 employees.

Data on innovation practices was collected through faceto-face interviews. A group of innovation consultants from a regional development agency held face-to-face interviews with representatives from each company. The interviews were conducted from a historical perspective, trying to capture information about the companies' innovative best practices during the period from 2000 to 2006. The face-to-face interview methodology has been shown to be especially effective when there is a high degree of technical complexity in the questions, and when the interviewer is a specialist in the matter (Doyle, 2006). This methodology allows the researcher to control the quality and real interest of the interviewed manager, in contrast with the uncertainty about the real degree of knowledge from managers responding to mailed surveys. During these visits (from October 2008 to February 2009), extended interviews were conducted with the managing director of each company. Each case company received approximately two hours of interviewing and telephone contact. In addition to the interviews, tours of factories, offices, warehouses, and stores were taken in all cases.

An initial questionnaire was designed and pre-tested with an initial subsample of 10 companies, in order to clarify and improve the questions. Subsequently, a total of 101 companies acceded to the interview, of 
which 9l we considered valid (10 questionnaires were discarded because the companies were a start-up with high innovation skills but still very young, six merged or were acquired during the study period, two were merely distribution centers and, finally, one only had an R\&D facility in Catalonia, which was a cost center and not a business unit). Of the surveys, $49.5 \%$ were carried out with the company's General Manager, $19.7 \%$ with the R\&D Manager, $16.4 \%$ with the Engineering Manager, $8.8 \%$ with Business Development managers, 3.3\% with Production Managers, and $2.19 \%$ with Quality Managers. The average length for each interview was 109 minutes.

\subsection{Variables}

Innovation behavior variables: Through the interview process, we captured the innovation behavior of companies through 93 questions that measure the degree of involvement of the companies in key activities, using a Likert scale from I to 7 . The interviewer guided the company to answer each question and assured a consistent enquiry procedure. Each interview generally followed the structure shown until we received answers for every question. A simplified outline is shown in Table I below.

\begin{tabular}{|c|c|}
\hline $\begin{array}{l}\text { INNOVATION } \\
\text { MANAGEMENT } \\
\text { DIMENSIONS }\end{array}$ & MAIN TOPICS \\
\hline INNOVATION STRATEGY & INNOVATION STRATEGY \\
\hline \multirow[t]{2}{*}{ MANAGEMENT SYSTEMS } & INNOVATION SYSTEMATIZATION \\
\hline & HUMAN RESOURCES MANAGEMENT \\
\hline \multirow[t]{2}{*}{ INNOVATION CULTURE } & TOLERANCE TO CHANGE AND ERROR \\
\hline & COOPERATIVE CULTURE \\
\hline CREATIVITY & SOURCES OF IDEAS \\
\hline \multirow[t]{3}{*}{ PROJECT MANAGEMENT } & INNOVATION PROJECTS MANAGEMENT \\
\hline & PROJECT'S PORTFOLIO \\
\hline & KNOWLEDGE MANAGEMENT \\
\hline \multirow[t]{3}{*}{ PRODUCT INNOVATION } & PRODUCT'S LIFECYCLE \\
\hline & NEW PRODUCT DEVELOPMENT \\
\hline & DESIGN \\
\hline \multirow[t]{2}{*}{ PROCESS INNOVATION } & PROCESS ENGINEERING \\
\hline & $\begin{array}{l}\text { PROCESS MANAGEMENT TOOLS } \\
\end{array}$ \\
\hline \multirow{2}{*}{$\begin{array}{l}\text { COMMERCIAL } \\
\text { INNOVATION }\end{array}$} & BRAND MANAGEMENT \\
\hline & NEW COMMERCIAL PRACTICES \\
\hline \multirow{5}{*}{$\begin{array}{l}\text { TECHNOLOGICAL } \\
\text { INNOVATION }\end{array}$} & TECHNOLOGY WATCH \\
\hline & R\&D DEPARTMENT \\
\hline & R\&D PUBLIC INCENTIVES/GRANTS \\
\hline & EXTERNAL TECHNOLOGY SOURCES \\
\hline & $\begin{array}{l}\text { INTELLECTUAL PROPERTY MANAGEMENT } \\
\end{array}$ \\
\hline
\end{tabular}

Table I: Survey structure 
Business performance (results) variables: According to our model, we selected three business results measures: sales growth, profit per employee, and return on assets. We used the SABI database to collect data of business results from 2000 to 2006, which was deemed a sufficient time span to ensure that the most successful companies, in an extremely fast-changing industry, had time enough to adapt their strategies in terms of continuous technological disruptions and strong international competence. We obtained data of the three financial figures for each company in our sample and calculated the sales growth rate, average profit per employee, and return on assets during the research period.

\section{Empirical Analysis}

\section{I. Innovation behavior of companies: exploratory factor analysis}

We initially speculated that the behavior of companies could be explained around the nine main innovation dimensions proposed in the conceptual model. For that purpose, an exploratory factor analysis was performed of the variables. Through the exploratory factor analysis of data, we found that these 93 questions proposed by literature could be reduced to 19 factors (see Appendix). Consequently, we recognize that some of the nine dimensions of innovation traditionally considered in the literature could be further subdivided into more refined elements; i.e., when talking about innovation strategy, our analysis shows that it may worthwhile to separately consider the overall strategic planning of the new product development planning, or that management systems innovation could be further subdivided into the control of quality systematization, project management systematization, or the systematization of innovation itself. In Table 2, we map our 19 factors to each of the nine relevant dimensions in our model. 


\begin{tabular}{|c|c|}
\hline DIMENSIONS & FACTORS \\
\hline \multirow{4}{*}{$\begin{array}{l}\text { INNOVATION } \\
\text { STRATEGY }\end{array}$} & EXISTENCE OF A STRATEGY PLANNING IN THE \\
\hline & MID- AND LONG-TERM, ACCORDING TO \\
\hline & EXTERNAL AND INTERNAL FACTORS \\
\hline & $\begin{array}{l}\text { PLANNING OF NEW PRODUCT DEVELOPMENTS IN } \\
\text { THE SHORT TERM }\end{array}$ \\
\hline \multirow{5}{*}{$\begin{array}{l}\text { MANAGEMENT } \\
\text { SYSTEMS }\end{array}$} & INNOVATION SYSTEMATIZATION \\
\hline & QUALITY SYSTEMATIZATION \\
\hline & PROJECT MANAGEMENT: PORTFOLIO, RISK, AND \\
\hline & CONTINUITY OF INNOVATION PROJECTS \\
\hline & $\begin{array}{l}\text { CAPTURING HIGH-LEVEL PROFESSIONAL } \\
\text { PROFILES }\end{array}$ \\
\hline INNOVATION & HAVING AN OPEN-MINDED CULTURE IN THE \\
\hline CULTURE & ORGANIZATION \\
\hline CREATIVITY & $\begin{array}{l}\text { DEVELOPMENT OF PROFESSIONAL CAREERS, } \\
\text { ROTATION BETWEEN AREAS AND MECHANISMS } \\
\text { TO ENCOURAGE NEW IDEAS AMONG EMPLOYEES }\end{array}$ \\
\hline $\begin{array}{l}\text { PROJECT } \\
\text { MANAGEMENT }\end{array}$ & KNOWLEDGE MANAGEMENT \\
\hline \multirow[t]{2}{*}{$\begin{array}{l}\text { PRODUCT } \\
\text { INNOVATION }\end{array}$} & $\begin{array}{l}\text { RELATIONSHIP WITH SUPPLIERS AS A SOURCE OF } \\
\text { IDEAS }\end{array}$ \\
\hline & DESIGN \\
\hline \multirow{4}{*}{$\begin{array}{l}\text { PROCESS } \\
\text { INNOVATION }\end{array}$} & ADVANCED METHODS AND ICT IN PRODUCT \\
\hline & DEVELOPMENT AND PRODUCTION \\
\hline & ADVANCED PRODUCTIVITY TOOLS IN PROCESSES \\
\hline & OPERATIVE FLEXIBILITY \\
\hline COMMERCIAL & BRAND MANAGEMENT \\
\hline
\end{tabular}

Table 2: Main innovation management patterns 


\subsection{Innovation behavior and firm structure: Clus- terization of innovative behavior}

In order to determine if there are innovation practices related to different industrial environments, we conducted a cluster analysis to classify companies according to their similar innovation practices, using each of the variables (innovation management practices). We used the complete-linkage method, where similarity between clusters is the smallest (minimum diameter) sphere that can enclose all observations in both clusters and assigns each observation (a 60-dimensional vector) to a cluster. The observation (company) is assigned to minimize the Euclidean distance.

Five clusters were found. Looking at the companies forming each cluster, we see that these five clusters corresponded to five different kinds of electronics companies (Fig. 4). These results show relevant relationships between the company typology and environment (size, structure, range of products, and position in the value chain) and innovation management practices, such as companies with similar typologies and environments also having similar innovative behaviors (Table 3). 


\begin{tabular}{|c|c|c|}
\hline Cluster & Innovation management practices & Type of company/Industrial context \\
\hline 1 & $\begin{array}{l}\text { Higher scores in all innovation } \\
\text { management practices, especially in } \\
\text { innovation systematization. } \\
\text { The worst behavior was found in } \\
\text { capturing high-level professional profiles. }\end{array}$ & $\begin{array}{l}\text { Size: Medium enterprises } \\
\text { Range of products: Manufacturing medical devices } \\
\text { or telecommunications products/services } \\
\text { Position in the value chain: Own product }\end{array}$ \\
\hline 2 & $\begin{array}{l}\text { Low scores in the majority of } \\
\text { variables. This is the cluster where a } \\
\text { better product design takes place. }\end{array}$ & $\begin{array}{l}\text { Size: Small companies (fewer than } 20 \text { employees) } \\
\text { Structure: Strong role of the CEO or director } \\
\text { Range of products: Very limited range, generally } \\
\text { with specific applications where design is a key factor } \\
\text { Position in the value chain: Own product }\end{array}$ \\
\hline 3 & $\begin{array}{l}\text { Low scores in all practices, important } \\
\text { differences found in project management, } \\
\text { much lower than in the rest of clusters. }\end{array}$ & $\begin{array}{l}\text { Size: Medium enterprises } \\
\text { Structure: Traditional management without } \\
\text { professionalization } \\
\text { Position in the value chain: Own product. They do } \\
\text { not develop technology and use local suppliers to get it }\end{array}$ \\
\hline 4 & $\begin{array}{l}\text { Good scores in product design and } \\
\text { operative flexibility, although branding is } \\
\text { not very relevant. }\end{array}$ & $\begin{array}{l}\text { Size: Medium enterprises } \\
\text { Range of products: Control and verification devices } \\
\text { and tools, including for industrial processes } \\
\text { Position in the value chain: Suppliers }\end{array}$ \\
\hline 5 & $\begin{array}{l}\text { High level of quality and branding. } \\
\text { This cluster does not show product } \\
\text { design and commercial innovation. }\end{array}$ & $\begin{array}{l}\text { Size: Medium-large enterprises } \\
\text { Structure: Professionalized } \\
\text { Position in the value chain: Big industry suppliers }\end{array}$ \\
\hline
\end{tabular}

Table 3: Relationship between company typology and environment 


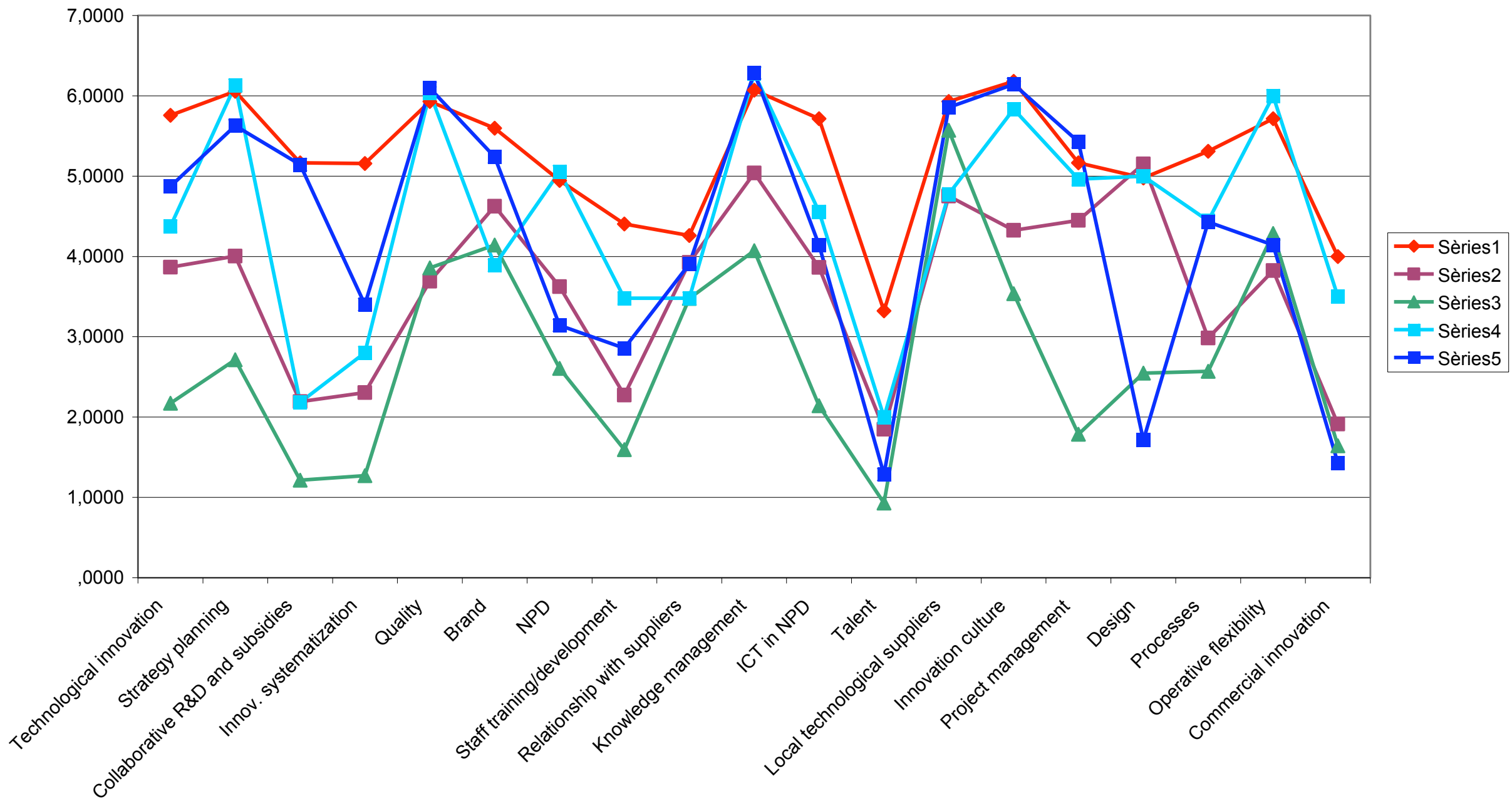

Figure 4:Average dimension scores for companies in each cluster 


\subsection{Link between innovation and results}

We wanted to further research the relationships in our model (Figure 3) between innovation management practices as they modify a company's resources and competences and business parameters, having had sustained business results from 2000 to 2006 .

\subsection{Cluster comparison}

In order to determine if innovation patterns related to different business performance in the mid- and long-term, we performed the following test:

Companies were ranked according to their positions concerning each of the three measures parameters (sales growth, profit per employee, and return on assets). In each case, ranks were divided in quartiles; each company was assigned to a quartile, from I to 4. Additionally, we compared the average of each cluster to find which ones had better business performance.

\section{Sales Growth}

$50 \%$ of companies from Cluster I and $42.86 \%$ from Cluster 5 belong to Quartile I (best performers) in sales growth, and only one of them (from Cluster 5) was ranked as a worst-performer (Quartile 4). On the other hand, 50\% of companies belonging to Cluster 2 showed the lowest results in turnover growth (Table 4). However, the chisquare test of independence showed no relationship between cluster membership and quartile distribution (asymp. sign. 2-sided= .196).

We found statistical significance showing that companies from Cluster I have higher results than Clusters 2, 3, and 4 in terms of turnover variation (Table 5).

\begin{tabular}{|c|c|c|c|c|c|}
\hline & $\begin{array}{c}\text { Quartile } 4 \\
\text { (less } \\
\text { competitive) }\end{array}$ & Quartile 3 & Quartile 2 & $\begin{array}{c}\text { Quartile 1 } \\
\text { (most } \\
\text { competitive) }\end{array}$ & Total \\
\hline Cluster 1 & $\begin{array}{l}0 \% \\
(0)\end{array}$ & $\begin{array}{c}14.29 \% \\
\text { (2) }\end{array}$ & $\begin{array}{c}35.71 \% \\
(5)\end{array}$ & $\begin{array}{c}50 \% \\
(7)\end{array}$ & $100 \%(14)$ \\
\hline Cluster 2 & $\begin{array}{c}50 \% \\
(7)\end{array}$ & $\begin{array}{c}21.43 \% \\
\text { (3) }\end{array}$ & $\begin{array}{c}7.14 \% \\
(1)\end{array}$ & $\begin{array}{c}21.43 \% \\
\text { (3) }\end{array}$ & $\begin{array}{c}100 \% \\
(14)\end{array}$ \\
\hline Cluster 3 & $\begin{array}{l}30 \% \\
(12)\end{array}$ & $\begin{array}{c}27.50 \% \\
(11)\end{array}$ & $\begin{array}{l}25 \% \\
(10)\end{array}$ & $\begin{array}{c}17.50 \% \\
(7)\end{array}$ & $\begin{array}{c}100 \% \\
(40)\end{array}$ \\
\hline Cluster 4 & $\begin{array}{c}22.22 \% \\
\text { (2) }\end{array}$ & $\begin{array}{c}22.22 \% \\
\text { (2) }\end{array}$ & $\begin{array}{c}33.33 \% \\
\text { (3) }\end{array}$ & $\begin{array}{c}22.22 \% \\
\text { (2) }\end{array}$ & $\begin{array}{c}100 \% \\
(9)\end{array}$ \\
\hline Cluster 5 & $\begin{array}{c}14.29 \% \\
\text { (1) }\end{array}$ & $\begin{array}{c}28.57 \% \\
(2)\end{array}$ & $\begin{array}{c}14.29 \% \\
(1)\end{array}$ & $\begin{array}{c}42.86 \% \\
\text { (3) }\end{array}$ & $\begin{array}{c}100 \% \\
(7)\end{array}$ \\
\hline
\end{tabular}

Table 4: Cluster distribution by quartiles according to sales growth

\begin{tabular}{|l|c|c|c|c|c|}
\hline Cluster & $\mathbf{1}$ & $\mathbf{2}$ & $\mathbf{3}$ & $\mathbf{4}$ & $\mathbf{5}$ \\
\hline 1- Average 1.6 & - & $\mathbf{0 . 0 0 1 * *}$ & $\mathbf{0 . 0 0 2} * *$ & $\mathbf{0 . 0 5 2} *$ & 0.255 \\
\hline 2- Average 2.7 & & - & 0.397 & 0.531 & 0.226 \\
\hline 3- Average 3 & & & - & 0.291 & 0.149 \\
\hline $4-$ Average 2.4 & & & & - & 0.616 \\
\hline 5- Average 2.1 & & & & & - \\
\hline
\end{tabular}

Table 5: T-test comparing cluster average of sales growth 


\section{Profit per employee}

Clusters I and 4 showed the best performance with $42.86 \%$ and $55.56 \%$ of the companies, respectively, in Quartile I, while Clusters 2 and 3 contain the $85.72 \%$ of the worst performers in terms of profit per employee (Quartile 4, Table 6). A Chi-square of 19.94 (asymp. sig. 2 -sided $=.068$ ) confirms this relationship between clusters and their distribution.
We found that Clusters I, 4, and 5, which showed more innovative behavior, were generally better than Clusters 2 and 3 , with a significant difference in their profit per employee media (Table 7).

\begin{tabular}{|c|c|c|c|c|c|}
\hline & $\begin{array}{c}\text { Quartile 4 } \\
\text { (less } \\
\text { competitive) }\end{array}$ & Quartile 3 & Quartile 2 & $\begin{array}{c}\text { Quartile 1 } \\
\text { (most } \\
\text { competitive) }\end{array}$ & Total \\
\hline Cluster 1 & $\begin{array}{c}7.14 \% \\
\text { (1) }\end{array}$ & $\begin{array}{c}21.43 \% \\
\text { (3) }\end{array}$ & $\begin{array}{c}28.57 \% \\
\text { (4) }\end{array}$ & $\begin{array}{c}42.86 \% \\
(6)\end{array}$ & $\begin{array}{r}100 \% \\
(14)\end{array}$ \\
\hline Cluster 2 & $\begin{array}{c}28.57 \% \\
\text { (4) }\end{array}$ & $\begin{array}{c}42.86 \% \\
(6)\end{array}$ & $\begin{array}{c}21.43 \% \\
\text { (3) }\end{array}$ & $\begin{array}{c}7.14 \% \\
\text { (1) }\end{array}$ & $\begin{array}{r}100 \% \\
(14)\end{array}$ \\
\hline Cluster 3 & $\begin{array}{l}35 \% \\
(14)\end{array}$ & $\begin{array}{c}22.50 \% \\
\text { (9) }\end{array}$ & $\begin{array}{l}30 \% \\
(12)\end{array}$ & $\begin{array}{c}12.50 \% \\
(5)\end{array}$ & $\begin{array}{r}100 \% \\
(40)\end{array}$ \\
\hline Cluster 4 & $\begin{array}{c}22.22 \% \\
\text { (2) }\end{array}$ & $\begin{array}{c}11.11 \% \\
(1)\end{array}$ & $\begin{array}{c}11.11 \% \\
\text { (1) }\end{array}$ & $\begin{array}{c}55.56 \% \\
(5)\end{array}$ & $\begin{array}{r}100 \% \\
(9)\end{array}$ \\
\hline Cluster 5 & $\begin{array}{l}0 \% \\
(0)\end{array}$ & $\begin{array}{c}28.57 \% \\
\text { (2) }\end{array}$ & $\begin{array}{c}42.86 \% \\
\text { (3) }\end{array}$ & $\begin{array}{c}28.57 \% \\
\text { (2) }\end{array}$ & $\begin{array}{r}100 \% \\
(7)\end{array}$ \\
\hline
\end{tabular}

Table 6: Cluster distribution by quartiles according to profit per employee

\begin{tabular}{|l|c|c|c|c|c|}
\hline Cluster & $\mathbf{1}$ & $\mathbf{2}$ & $\mathbf{3}$ & $\mathbf{4}$ & $\mathbf{5}$ \\
\hline 1- Average 1.9 & - & $\mathbf{0 . 0 1 * *}$ & $\mathbf{0 . 0 1 * *}$ & 0.884 & 0.872 \\
\hline 2- Average 2.8 & & - & 0.69 & $\mathbf{0 . 0 5 8 *}$ & $\mathbf{0 . 0 6 6 *}$ \\
\hline 3- Average 2.9 & & & - & $\mathbf{0 . 0 5 9 *}$ & $\mathbf{0 . 0 3 6 * *}$ \\
\hline 4- Average 2 & & & & - & 1 \\
\hline 5- Average 2 & & & & & - \\
\hline
\end{tabular}

Table 7: T-test comparing cluster average for profit per employee 


\section{Return on assets (ROA)}

The analysis relating clusters to their position on quartiles measured according to their return on assets media showed that Clusters $I$ and 5 were statistically better than 2 and 3 (Table 9), with $57.14 \%$ and $33.33 \%$ of the companies, respectively, in Quartile I (Table 8), confirmed by the chi-square independence test $\left(X^{2}=23.09\right.$, asym. sign. 2-sided= .027).

\begin{tabular}{|c|c|c|c|c|c|}
\hline & $\begin{array}{c}\text { Quartile } 4 \text { (less } \\
\text { competitive) }\end{array}$ & Quartile 3 & Quartile 2 & $\begin{array}{c}\text { Quartile 1 } \\
\text { (most } \\
\text { competitive) }\end{array}$ & Total \\
\hline Cluster 1 & $\begin{array}{c}7.14 \% \\
(1)\end{array}$ & $\begin{array}{l}14.29 \% \\
\text { (2) }\end{array}$ & $\begin{array}{l}21.43 \% \\
\text { (3) }\end{array}$ & $\begin{array}{l}57.14 \% \\
(8)\end{array}$ & $\begin{array}{r}100 \% \\
(14)\end{array}$ \\
\hline Cluster 2 & $\begin{array}{l}35.71 \% \\
(5)\end{array}$ & $\begin{array}{c}42.86 \% \\
(6)\end{array}$ & $\begin{array}{c}7.14 \% \\
(1)\end{array}$ & $\begin{array}{l}14.29 \% \\
\text { (2) }\end{array}$ & $\begin{array}{r}100 \% \\
(14)\end{array}$ \\
\hline Cluster 3 & $\begin{array}{c}32.50 \% \\
(13)\end{array}$ & $\begin{array}{c}27.50 \% \\
(11) \\
\end{array}$ & $\begin{array}{c}27.50 \% \\
(11)\end{array}$ & $\begin{array}{c}12.50 \% \\
(5)\end{array}$ & $\begin{array}{r}100 \% \\
(40)\end{array}$ \\
\hline Cluster 4 & $\begin{array}{l}22.22 \% \\
\text { (2) }\end{array}$ & $\begin{array}{c}11.11 \% \\
(1)\end{array}$ & $\begin{array}{c}33.33 \% \\
\text { (3) }\end{array}$ & $\begin{array}{c}33.33 \% \\
\text { (3) }\end{array}$ & $\begin{array}{r}100 \% \\
(9)\end{array}$ \\
\hline Cluster 5 & $\begin{array}{l}0 \% \\
(0) \\
\end{array}$ & $\begin{array}{c}14.29 \% \\
(1)\end{array}$ & $\begin{array}{c}57.14 \% \\
\text { (4) }\end{array}$ & $\begin{array}{l}28.57 \% \\
\text { (2) }\end{array}$ & $\begin{array}{r}100 \% \\
(7)\end{array}$ \\
\hline
\end{tabular}

Table 8: Cluster distribution by quartiles according to return on assets

\begin{tabular}{|l|c|c|c|c|c|}
\hline Cluster & $\mathbf{1}$ & $\mathbf{2}$ & $\mathbf{3}$ & $\mathbf{4}$ & $\mathbf{5}$ \\
\hline 1- Average 1.7 & - & $\mathbf{0 . 0 0 1 * *}$ & $\mathbf{0 . 0 0 2 1 * *}$ & 0.283 & 0.738 \\
\hline 2- Average 2.8 & & - & 0.539 & 0.15 & $\mathbf{0 . 0 2 6 * *}$ \\
\hline 3- Average 3 & & & - & 0.114 & $\mathbf{0 . 0 1 7 * *}$ \\
\hline 4- Average 2.2 & & & & - & 0.487 \\
\hline 5- Average 1.8 & & & & & - \\
\hline
\end{tabular}

Table 9: T-test comparing cluster average of return on assets 


\section{Average rank}

A final test was carried out with an integrated ranking. In order to capture the relative performance position of the company along multiple dimensions and also in an aggregate construct, we followed a methodology similar to the approach recommended by Rouse \& Daellenbach (1999) and Eunni (2005). Data for each dependent variable (performance measure) was separately tabulated in a descending order, and all of the companies were ranked. The ranks were averaged to obtain a mean rank score, then the companies were arranged in descending order of these mean scores. Finally, the companies in the panel were the divided into four final quartiles, to measure overall performance based on the mean quartile scores.

All the results found by the analysis demonstrate that Clusters I, 4, and 5 - especially I and 5 - are better performers than 2 and 3 (Tables 10 and $1 \mathrm{I}, \mathrm{X}^{2}=23.69$, asym. sign. 2-sided $=.022$ ), but we can't determine which variables fix these differences, as there is also a relationship between innovation practices and the company context.

\begin{tabular}{|c|c|c|c|c|c|}
\hline & \begin{tabular}{|c} 
Quartile 4 (less \\
competitive)
\end{tabular} & Quartile 3 & Quartile 2 & $\begin{array}{c}\text { Quartile } 1 \text { (most } \\
\text { competitive) }\end{array}$ & Total \\
\hline Cluster 1 & $\begin{array}{l}0 \% \\
(0)\end{array}$ & $\begin{array}{l}14.29 \% \\
(2)\end{array}$ & $\begin{array}{l}28.57 \% \\
(4)\end{array}$ & $\begin{array}{l}57.14 \% \\
(8)\end{array}$ & $\begin{array}{r}100 \% \\
(14)\end{array}$ \\
\hline Cluster 2 & $\begin{array}{c}50 \% \\
(7)\end{array}$ & $\begin{array}{l}14.29 \% \\
\text { (2) }\end{array}$ & $\begin{array}{l}21.43 \% \\
\text { (3) }\end{array}$ & $\begin{array}{l}14.29 \% \\
\text { (2) }\end{array}$ & $\begin{array}{r}100 \% \\
(14)\end{array}$ \\
\hline Cluster 3 & $\begin{array}{l}30 \% \\
(12)\end{array}$ & $\begin{array}{l}35 \% \\
(14)\end{array}$ & $\begin{array}{l}22.50 \% \\
\text { (9) }\end{array}$ & $\begin{array}{c}12.50 \% \\
(5)\end{array}$ & $\begin{array}{r}100 \% \\
(40)\end{array}$ \\
\hline Cluster 4 & $\begin{array}{l}22.22 \% \\
\text { (2) }\end{array}$ & $\begin{array}{c}11.11 \% \\
\text { (1) }\end{array}$ & $\begin{array}{l}33.33 \% \\
\text { (3) }\end{array}$ & $\begin{array}{c}33.33 \% \\
\text { (3) }\end{array}$ & $\begin{array}{r}100 \% \\
(9)\end{array}$ \\
\hline Cluster 5 & $\begin{array}{l}0 \% \\
(0)\end{array}$ & $\begin{array}{l}28.57 \% \\
(2)\end{array}$ & $\begin{array}{l}42.86 \% \\
\text { (3) }\end{array}$ & $\begin{array}{l}28.57 \% \\
(2)\end{array}$ & $\begin{array}{r}100 \% \\
(7)\end{array}$ \\
\hline
\end{tabular}

Table 10: Cluster distribution by quartiles according to the average rank

\begin{tabular}{|l|c|c|c|c|c|}
\hline Cluster & $\mathbf{1}$ & $\mathbf{2}$ & $\mathbf{3}$ & $\mathbf{4}$ & $\mathbf{5}$ \\
\hline 1- Average 1.5 & - & $0.000^{* *}$ & $0.001^{* *}$ & 0.124 & 0.247 \\
\hline 2- Average 2.8 & & - & 0.595 & 0.125 & $0.047^{* *}$ \\
\hline 3- Average 3 & & & - & 0.14 & $0.059^{*}$ \\
\hline 4- Average 2.2 & & & & - & 0.682 \\
\hline 5- Average 2 & & & & & - \\
\hline
\end{tabular}

Table II: T-test comparing cluster average rank 


\subsubsection{Linear regression model}

In order to find which innovation practices are most related to business performance, we built a lineal regression model according to our model, where business performance is the dependent variable and a function of innovation management practices (independent variables).

Three regressions have been run with the three business results indicators.

\section{Turnover variation}

Table 12 represents the results of the regression where turnover variation is the dependent variable explained by innovation management practices.

There is significant evidence that some innovation management practices influence business turnover (the model adjusted R-square was 0.227, with an F-test significance of 0.007). Two innovation practices are strongly supported: companies with high innovation systematization tend to increase their turnover, and those who use advanced methods and ICT in product development and production exhibit a higher propensity for improvement in their sales.

Innovation practices like design management, capturing high-level professional profiles, collaborative R\&D projects, using public subsidies, and the use of local technology suppliers is negatively related to turnover levels, which could show the immature technology level of suppliers or difficulties in technology transfer. Further research is needed to clarify this point. 


\begin{tabular}{|c|c|c|c|c|c|}
\hline & \multicolumn{2}{|c|}{$\begin{array}{c}\text { Non-standardized } \\
\text { Coefficients }\end{array}$} & \multirow{2}{*}{$\begin{array}{c}\begin{array}{c}\text { Standardized } \\
\text { Coefficients }\end{array} \\
\text { Beta }\end{array}$} & \multirow[b]{2}{*}{$\mathrm{t}$} & \multirow[b]{2}{*}{ Sig. } \\
\hline & $\mathrm{B}$ & Std. Error & & & \\
\hline (Constant) & -18.591 & 87.612 & & -.212 & .833 \\
\hline Innovation strategy & 7.976 & 8.701 & .125 & .917 & .363 \\
\hline Innovation systematization & 3.765 & 13.819 & .039 & .272 & .786 \\
\hline Product lifecycle planning & 28.401 & 13.265 & .377 & 2.141 & $.036 * *$ \\
\hline Quality systematization & -12.114 & 8.489 & -.182 & -1.427 & .158 \\
\hline Project management & -9.145 & 10.960 & -.122 & -.834 & .407 \\
\hline $\begin{array}{l}\text { Advanced methods and ICT in } \\
\text { product and production }\end{array}$ & 26.969 & 11.060 & .356 & 2.438 & $.018 * *$ \\
\hline Process management tools & 10.395 & 10.937 & .147 & .951 & .345 \\
\hline Process engineering & 7.466 & 6.554 & .121 & 1.139 & .259 \\
\hline Brand management & 11.055 & 9.982 & .120 & 1.107 & .272 \\
\hline Design & -16.410 & 8.797 & -.239 & -1.866 & $.067 *$ \\
\hline New commercial practices & 12.833 & 10.376 & .160 & 1.237 & .221 \\
\hline Professional development & -13.355 & 12.032 & -.155 & -1.110 & .271 \\
\hline Knowledge management & -11.532 & 9.398 & -.157 & -1.227 & .224 \\
\hline High-level professional profiles & -23.241 & 11.047 &,- 271 & -2.104 & $.039 * *$ \\
\hline Tolerance to change and error & 10.787 & 9.364 & .146 & 1.152 & .254 \\
\hline Technological innovation & 13.387 & 13.247 & .168 & 1.011 & .316 \\
\hline Collaborative R\&D and subsidies & -24.194 & 8.461 & -.398 & -2.859 & $.006 * *$ \\
\hline Relationship with suppliers & 11.554 & 9.486 & .139 & 1.218 & .228 \\
\hline Local technology suppliers & -14.951 & 8.630 & -.202 & -1.732 & $.088 *$ \\
\hline
\end{tabular}

Table 12: Regression results with turnover as a dependent variable 


\section{Average profit per employee and return on assets}

Models where profit per employee and return on assets as independent variables explained by innovation management practices did not show an acceptable R-coefficient and F-test, so there is no significant evidence that some innovation management practices influence these business results indicators.

\section{Discussion}

Our empirical analysis reveals that, depending on the industrial environment, companies use different innovation management practices. Nevertheless, for the entire sample, the systematization of innovation is the main factor positively related to improvements in business performance. This is in agreement with some previous results in other contexts. For instance, Battisti and lona (2009) found that establishment size, ownership structure, and product market concentration are important determinants of the intensity of management practices in the British establishment. Our research shows that something similar may happen in the high-technology sector. Each of the five clusters of companies corresponds to a particular industrial environment and, at the same time, seems to be related to a different degree of innovation management. For instance, the first cluster formed by companies with a high level of innovation management corresponds to medium-sized companies in the subsector of medical devices and telecommunications. On the other hand, companies in the second cluster tend to be smaller companies with strong leadership (i.e., traditional family-type business) and a limited range of products and, commonly, show low levels of innovation management. The third cluster contains medium-sized companies with little professionalization in the management team and with poor skills in innovation project management. The fourth one is also formed by medium-sized companies suppliers of control and verification devices - that showed strong design management and operative flexibility, but no capabilities for branding. Finally, the last cluster belongs to medium and large companies that are professionalized, are suppliers for multinational companies, and have high levels of quality of branding but low levels of design and commercial innovation.
Concerning the relationship between clusters and business performance, our research concludes that Clusters I, 4, and 5 are better performers than 2 and 3 when looking at the three dependent variables - sales growth, profit per employee and ROA - during the period of study.

We found significant statistical evidence of a relationship between different innovation management practices and business results. Our results demonstrate that companies with poor innovation management practices and without innovation project management skills perform worse than the rest of the sector.

Based on the examination of innovation practices and business performance through a lineal regression model, it appears that innovation practices can explain sales growth but not improvements in profit per employee and ROA.

We can partially confirm $\mathrm{H} 3 \mathrm{a}$, as we found that internal alignment is related to business performance, but only in the case of practices that change companies' resources and competences. Among them, innovation systematization is positively related to sales growth, while capturing high-level professional profiles has a negative effect. This negative relationship could be explained by the fact that the Catalan electronics sector is not highly internationalized, and the incorporation of such profiles does not facilitate the knowledge of local markets. This hypothesis should be confirmed with future research.

Finally, we cannot confirm $\mathrm{H} 3 \mathrm{~b}$ as our results showed that external alignment measures, specifically collaborative R\&D and subsidies, design management, and the use of local technology suppliers are negative related to business performance in terms of sales growth. Only the use of advanced methods (i.e., FMEA, PdM, and business excellence models) and ICT in products and production have positive effects on companies' results.

One possible explanation is that company managers have a different perception of what design is, maybe thinking that only by including some minor cosmetic aspects they are already innovating in the design of their products. Regarding the negative impact of collaborative R\&D projects and the of use public subsidies, our result are surprising. In some mature sectors, previous research shows that companies that experience continuous reduction in turnover seek cooperation in R\&D activities to research new markets and opportunities, but that this 
J. Technol. Manag Innov. 20II,Volume 6, Issue 2

late reaction seldom leads to improved results in the long term (Hagedoorn, 1993). As such, our results may be biased regarding this problem. Finally, the negative effect of the use of local technology suppliers could show the immature technology levels of suppliers or difficulties in technology transfer. Further research is needed to solve these issues.

\section{Conclusions}

A new model has been developed to explain the innovative behavior of Catalan electronics companies, where 19 constructs cover those innovation practices that distinguish business behavior.

According to this model, the cluster analysis showed five clusters with different innovative behaviors and, looking at the companies that form them, we found that they have also differences in the type of company and industrial context.

There is evidence that the best performing companies have innovation management practices above the average (innovative behavior). Never theless, we should confirm the hypothesis that innovation management practices, and not the industrial context, are positively related to strategic adaptation capabilities toward a changing environment.

There is also a possible industry-related effect in the results. Applying the same research process to another industry (retail, service, aerospace) could give different results, due to different industry dynamics, especially in those with more industry-sensitive parameters, like product innovation, process innovation, or commercial innovation.

Further research lines can be opened to explore our cluster analysis in a deeper way: which relationship with business results is stronger within the industrial context or innovation management practices.

We can also analyze each innovation management practice with business performance figures (sales growth, profit per employee, return on assets) in order to understand the underlying logic of the impact of the concrete practice in each performance indicator. Finally, new research projects could be launched to contrast the new theoretical model and its results in other industries (i.e., automotive, agricultural, food processing, industrial equipment).

\section{References}

ADAMS, R., Bessant, J., Phelps, R. (2006). Innovation management measurement: $A$ review. International Journal of Management Reviews 8 (I), 2I-47.

ADLER, P.S., Shenbar, A. (1990). Adapting your technological base: the organisational challenge. Sloan Management Review 25, 25-37.

ADLER, P.S., McDonald, W.D., McDonald, F.(1992). Strategic management of technical functions. Sloan Management Review 33(2), 19-37.

ALDRICH, H.E. (1979). Organizations and Environments. Prentice-Hall, Englewood Cliffs, New Jersey.

ANDREWS, K.R. (197I). The Concept of Corporate Strategy. Homewood, III, Irwin.

ANSOFF, I. (1965). Corporate Strategy. McGraw-Hill, New York.

AVLONITIS, G., Papastathopoulou, P. y Gounaris, S. (200I). An empirically - based typology for product innovativeness for new financial services: success and failure scenarios. The Journal of Product Innovation Management 18, 324-342.

BARCLAY, I. (1992). New product development process: past evidence and future practical application. R\&D Management 22 (3), 255-264.

BARNEY, J. B. (1991). Firm resources and sustained competitive advantage. Journal of Management 17, 99-120.

BATTISTI, G., Iona, A. (2009). The intra-firm diffusion of complementary innovations: Evidence from the adoption of management practices by British establishments. Research Policy 38(8), I326-1339.

BAYUS, B. L., Erickson, G., Jacobson, R. (2003). The financial rewards of new product introductions in the personal computer industry. Management Science 49 (2), 197-210.

BECKER, B., Gerhart, B. (1996). The Impact of Human Resource Management on Organizational Performance: Progress and Prospects. The Academy of Management Journal 39 (4), 779-80I. 
BLINDENBACH-DRIESSEN, F., Ende, J. (2006). Innovation in project-based firms: The context dependency of success factors. Research Policy 35(4), 545-56I.

BURGELMAN, R.A., Maidique, M.A., Wheelwright, S.C. (2004). Strategic Management of Technology and Innovation. McGraw Hill, New York.

BURNS, T., Stalker, G. (196I). The Management of Innovation. Tavistock Publications, London.

CHANDLER, A.D. (1962). Strategy and Structure: Chapters in the History of the American Industrial Enterprise. MIT Press, Cambridge, Mass.

CHIESA, V., Coughlan, P., Voss, C.A. (1996). Development of a technical innovation audit. Journal of Product Innovation Management 13(2), 105-136.

CHILD, J. (1997). Strategic choice in the analysis of action, structure, organizations and environment: Retrospect and prospect. Organization Studies I8(I), 43-76.

CHRISTENSEN, J.F. (1995). Asset profiles for technological innovation. Research Policy 24(5), 727-745.

CHRISTENSEN, C. M. (1997). The Innovator's Dilemma: When New Technologies Cause Great Firms to Fail. Harvard Business School Press, Boston.

COLLINS, J., Porras, J. I. (1994). Built to last. HarperBusiness, New York.

COOMBS, R., Hull, R. (1998). Knowledge management practices' and path-dependency in innovation. Research Policy 27(3), 237-253.

COOPER, R.G., Kleinschmidt, E.J. (1995). Benchmarking firms' new product performance and practices. Engineering Management Review, 23 (3), II2-120.

COOPER, R.G., Edgett, S.J., Kleinschmidt, E.J. (2004). Benchmarking best NPD practices-II. Reseach Technology Management 47(3), 50-59.

COOPER, R.G., Kleinschmidt, E.J. (1991). The impact of product innovativeness on performance. Journal of Product Innovation Management 8(4), 240-25I.
CORMICAN, K., O'Sullican, D. (2004). Auditing best practice for effective product innovation management. Technovation 24 (I0), 819-829.

CRAWFORD, C.M. (1980). Defining the charter for product innovation. Sloan Management Review (Fall), 3-12.

DAMANPOUR, F. (1991). Organizational innovation: A meta-analysis of effects of determinants and models. Academy of Management Journal 34(3), 555-90.

D'AVENI, R.A.(1994). Hypercompetition:Managing theDynamics of Strategic Maneuvering, New York, The Free Press.

DELERY, J. E., Doty, D. H. (1996). Modes of Theorizing in Strategic Human Resource Management: Tests of Universalistic, Contingency, and Configurational Performance Predictions. The Academy of Management Journal 39 (4), 802-835.

DIEDRICHS, E., Engel, K., Wagner, K. (2006). European Innovation Management Landscape: IMP3ROVE: Assesment of current practices on Innovation Management Consulting Approaches and self-assesment tools in Europe to define the requirements for future best practices. European Comission, Directorate General Enterprise and Industry, Augsburg

DONALDSON, G., Lorsch, J. W. (1983). Decision-making at the top: The shaping of strategic direction. Basic Books, New York.

DOYLE, J.K. (2006). Introduction to Survey Methodology and Design. Handbook for IQP Advisors and Students. D W Woods, ed.: Worcester Polytechnic Institute.

DRUCKER, F. (1954). The Practice of Management. Harper \& Bros., New York.

EUNNI, R.V., Post, J.E., Berger, P.D. (2005). Adapt or adapt: Lessons for strategy from the US telecoms industry. Journal of General Management 3I(I), 83-I05.

FLOYD, S. W., Lane, P. J. (2000). Strategizing throughout the Organization: Managing Role Conflict in Strategic Renewal. The Academy of Management Review 25 (I), I54- 177. 
GOFFIN, K., Pfeiffer, R. (1999). Innovation Management in UK and German Manufacturing Companies. Anglo-German Foundation for the Study of Industrial Society, London.

GRANT, R.M. (2005). Contemporary strategy analysis, 5th Ed., Wiley, Oxford.

GUAN, J., Yam, R., Tang, E., Lau, A. (2009). Innovation strategy and performance during economic transition: Evidences in Beijing, China. Research Policy 38 (5), 802-812.

HAGEDOORN, J. (1993). Understanding the rationale of strategic technology partnering: Interorganizational modes of cooperation and sectoral differences. Strategic Management Journal 14, 37I-385.

HAMEL, G., Prahalad, C.K. (1994). Competing for the future. Harvard Business Review 72(4), 122-128.

HANNAN, M.T., Freeman, J.H. (1984). Structural inertia and organization change. American Sociological Review 49, 149-164.

HELFAT, C.E., Peteraf, M.A. (2003). The Dynamic resource-based view: Capability lifecycle. Strategic Management Journal 24(I0), 997-1010.

HENARD, D.H., Szymanski, D.M. (200I). Why some new products are more successful than others. Journal of Marketing Research 38(3), 362-375.

HIPPEL, E.V. (1986). Lead user: A source of novel product concepts. Management Science 32(7), 79I-805.

HIPPEL, E.V. (1988). The Sources of Innovation. Oxford University Press, Oxford.

HIPPEL, E.V. (2005). Democratizing Innovation. The MIT Press, Cambridge, Mass.

HUERGO, E. (2006). The role of technological management as a source of innovation: Evidence from Spanish manufacturing firms. Research Policy 35(9), 1377-1388.

HUFF, A.S. (1990). Mapping Strategic Thought. John Wiley \& Sons, New York.
HULT, G.T.M, Hurley, R., Kingth. G. (2004). Innovativeness: Its antecedents and impact in business performance. Industrial Marketing Management 33, 429-438.

KANTER, R. M. (1983). The change masters: Innovation for productivity in the American corporation. Simon and Schuster, New York.

KIM, B. and Oh, H. (2002). An effective R\&D performance measurement system: survey of Korean R\&D researchers. International Journal of Management Science 30, |9-31.

KLINE, S.J. (1985). Innovation is not a linear process. Research Management (July-August), 36-45.

LAURIE, D.L., Doz, Y.L., Sheer, C.P. (2006). Creating new growth platforms. Harvard Business Review (May), 80-90.

LEONARD-BARTON, D. (1992). Core capabilities and core rigidities: A paradox in managing new product development. Strategic Management Journal I3 (SI), III-125.

LEE, S., Park, G., Yoon, B., Park, J. (2010). Open innovation in SMEs-An intermediated network model. Research Policy 39 (2), 290-300.

MARQUIS, D. (1969). The Anatomy of Succesful Innovations. Innovation Magazine I(7), 28-37.

MILES, R., Snow, C.C. (1978). Organization strategy, structure and process. McGraw Hill, New York.

MILTENBURG, J. (1995). Manufacturing Strategy, How to Formulate and Implement a Winning Plan. Productivity Press, Oregon.

OAKEY,R., Rothwell, R., Cooper.C.(1988). Management of Innovation in High Technology Small Firms. Pinter, London.

OBSERVATORI de Prospectiva Industrial (2005). Map of Local Industrial Production Systems in Catalonia. Generalitat de Catalunya, Barcelona.

OBSERVATORI de Prospectiva Industrial (2006). Informe Anual sobre la Industria a Catalunya. Generalitat de Catalunya. Generalitat de Catalunya, Barcelona.

PARKER, R. C. (1982). The management of innovation. Wiley, Chichester, UK. 
PAUWELS, K., Silva-Risso, J., Srinivasan, S., Hanssens, D. M. (2004). New Products, Sales Promotions, and Firm Value: The Case of the Automobile Industry. Journal of Marketing 68, I42-156.

PENROSE, E. (1959). The Theory of the Growth of the Firm. John Wiley \& Sons, New York.

PORTER, M.E. (1980). Competitive Strategy. The Free Press, New York.

PORTER, M.E. (1985). Competitive Advantage. The Free Press, New York.

PORTER, M.E. (1986a). Competition in Global Industries. Harvard Business School Press, Boston, Mass.

PORTER, M.E. (1986b). Changing patterns of international competition. California Management Review 28 (2), 9-40.

PORTER, M.E. (1990). The competitive advantage of nations. Harvard Business Review 68, 73-93.

PORTER, M.E. (1991). Towards a dynamic theory of strategy. Strategic Management Journal 12, 95-II7.

PRAHALAD, C. K., Hamel, G. (1990). The core competence and corporation. Harvard Business Review 3, 7I-9I.

ROSEGGER, G. (1980). The Economics of Production and Innovation. Pergamon Press, Oxford.

RUMELT, R.P. (1974). Strategy, Structure and Economic Performance. Harvard University Press, Cambridge, Mass.

SCHMIEDEBERG, C. (2009). Complementarities of innovation activities: An empirical analysis of the German manufacturing sector. Research Policy 37(9), 1492-1503.

SCHMOOKLER, J. (1966). Invention and Economic Growth. Harvard University Press, Cambridge, Mass.

SCHUMPETER, J. (1934). The Theory of Economic Development. Cambridge University Press, Cambridge, England.

SELZNIK, P. (1957). Leadership in Administration. Harper \& Bros., New York.
SLOAN, A.P. (1963). My Years with General Motors. Doubleday, Garden City, New York.

SORESCU, A.B., Chandy, R.K., Prabhu,J.C. (2003). Sources and finantial consequences of radical innovation: Insights from pharmaceuticals. Journal of Marketing 67, 82-102.

TALKE, K. (2007). Corporate mindset of innovating firms: Influences on new product performance. Journal of Engineering and Technology Management 24(I-2), 76-9I.

TAYLOR, F W. (19II). The Principles of Scientific Management. Harper \& Row, New York.

TEECE, D.J., Pisano, G., Shuen, A. (1992). Dynamic capabilities and strategic management. Working paper. University of California, Berkeley.

TERRÉ, E. (1999). Guia per Gestionar la Innovació. CIDEM, Barcelona.

THOMSON, J.D. (1967). Organizations in Action: Social Science Bases of Administrative Theory. McGraw-Hill, New York.

TIDD, J. (200I). Innovation management in context: Environment, organization, and performance. International Journal of Management Review 3, 169-183.

TIDD, J. (2006). A Review of Innovation Models. Discussion paper. Imperial College, Tanaka Business School.

TIDD, J., Bessant, J., Pavitt, K. (2005). Managing Innovation: Integrating Technological, Market and Organizational Change (3rd ed.). John Wiley \& Sons, New York.

TOMAS, M., Hurley, R., Knight, G. (2004). Innovativeness: Its antecedents and impact on business performance. Industrial Marketing Management 33, 429-438.

VAN DEN VEEN, A.H. (1986). Central problems in management of innovation. Management Science 32(5), 590-607.

VAN DE VEEN, A.H., Poole, M.S. (1990). Longitudinal field research methods for studying processes of organizational change. Organization Science I, 2I3-2I9. 
VAN DE VEEN, A.H., Poole, M.S. (1995). Managerial and organizational cognition: Notes from a trip down memory lane. Organizational Science 6, 280-32I.

VAN DE VEEN, A.H. (2000). Research on the Management of Innovation. Oxford University Press, New York VERHAEGHE, A., Kfir, R. (2002). Managing innovation in a knowledge intensive organisation. R\&D Management $32,409-417$.

WIRTZ, B., Mathieu, A., Schilke, O. (2007). Strategy in high velocity environments. Long Range Planning 40, 295-313.

YAM, R.C.M., Guan, J.C., Pun, K.F., Tang, E.P.Y. (2004). An audit of technological innovation capabilities in Chinese firms: Some empirical findings in Beijing, China. Research Policy 33(8), II23-II40.

YOUNDT, M., Snell, S., Dean, J., Lepak, D. (1996). Human resource management, manufacturing strategy, and firm performance.AcademyofManagementJournal39,836-866. 
J. Technol. Manag Innov. 20II,Volume 6, Issue 2 